\title{
G タンパク質共役型受容体の新たな機能及び調節機構
}

中畑則道

\section{Novel Functions and Regulatory Mechanisms of G Protein-coupled Receptors}

\author{
Norimichi NAKAHATA \\ Department of Cellular Signaling, Graduate School of Pharmaceutical Sciences, Tohoku University, \\ and Tohoku University 21st Century COE Program 'CRESCENDO', 6-3 Aoba, \\ Aramaki, Aoba-ku, Sendai City 980-8578, Japan
}

細胞膜に存在する 7 回膜貫通型構造を有する $\mathrm{G}$ タンパク質共役型受容体 (G protein-coupled receptor；GPCR）は，現在臨床で用いられている薬物の 約半数が作用点とする部位である.したがって, GPCR を介する細胞情報伝達機序及びその調節機 構の解明は, 薬の分子作用機序の解明や安全な薬物 の使用法の確立，さらに新しい GPCR 作動薬の創 薬研究において極めて重要である.

サザーランドのセカンドメッセンジャー理論に始 まった GPCR のシグナル伝達研究は, GPCRによ つて直接活性化される三量体 $\mathrm{G}$ タンパク質として $\mathrm{G}_{\mathrm{s}}, \mathrm{G}_{\mathrm{i}}, \mathrm{G}_{\mathrm{q}}$ 及び $\mathrm{G}_{12}$ ファミリーの存在することが明 らかになり，それぞれのファミリーに属する多様な $\mathrm{G}$ タンパク質を介してシグナル伝達が引き起こさ れることが明らかになった。 サイクリック AMP の 合成を促進する $\mathrm{G}_{\mathrm{s}}$ と抑制する $\mathrm{G}_{\mathrm{i}}$ によるアデニル酸 シクラーゼ/サイクリック AMP 系の調節に加えて, $\mathrm{G}_{\mathrm{q}}$ によるホスホリパーゼ C の活性化を介するイノ シトールリン脂質水解反応による細胞内 $\mathrm{Ca}^{2+}$ 動員 性のイノシトール 1,4,5- 三リン酸 $\left(\mathrm{IP}_{3}\right)$ とプロテ インキナーゼ C を活性化するジアシルグリセロー ルの生成系，そして細胞骨格などを制御する低分子 量 $\mathrm{G}$ タンパク質の Rho の活性を制御する $\mathrm{G}_{12}$ など が明らかになって，GPCR のシグナル伝達の中心 的な経路は確立した感がある.

しかし, 最近の研究から GPCR を介するシグナ

東北大学大学院薬学研究科細胞情報薬学分野, 東北大 学 21 世紀 COE プログラム“CRESCENDO” (テ9808578 仙台市青葉区荒巻字青葉 6-3)

e-mail: nakahata@mail.pharma.tohoku.ac.jp 日本薬学会第 126 年会シンポジウムS21 序文
ル伝達はかならずしも単純な経路ではなく，今まで 知られていない受容体の新しい機能が見出されると ともに, 受容体の活性が多くの機構によって調節さ れていることが明らかになってきた，例えば，同じ GPCR に作用するアゴニストの化学構造をわずか に変えると，異なる G タンパク質の活性化が引き 起こされることが報告されている。，一方，受容体遺 伝子の発現実験からアゴニストが存在しなくても受 容体が活性化していることがあり，今まで受容体の アンタゴニストと言われていた薬物が, 内因性の活 性を積極的に抑制するインヴァースアゴニストと, 単に受容体に結合するだけのニュートラルアンタゴ ニストに分類されている。ささらに，アゴニストが結 合して活性化した GPCR は，2 種類以上の G タン パク質の活性化を引き起こすことが報告されてい る。分子論的にみると, GPCR の大きさは $50 \mathrm{kDa}$ 前後であり, 三量体 $\mathrm{G}$ タンパク質の大きさは 80 $\mathrm{kDa}$ 前後である. したがって, GPCR 1 分子には 2 種類以上の三量体 $\mathrm{G}$ タンパク質が同時には結合し 難い。そうすると, GPCR は何らかの方法で三量 体 G タンパク質を区別するか，ある種の調節機構 の存在が考えられるが, 現在のところその機序は不 明なままである。また， GPCR のC末は細胞内に 存在するが，そこに三量体 $\mathrm{G}$ タンパク質以外の様 々なタンパク質が結合することが示されている，C 末には G タンパク質共役型受容体キナーゼ（GRK） によってリン酸化を受ける部位が存在し, 受容体 C 末がリン酸化されると, アレスチンが会合して, シ グナル伝達が停止するとともに，受容体の脱感作が 起こり, インターナリゼーションが惹起される. GPCR のC 末にはアレスチン以外にも多種のタン 
パク質が会合することが最近見出され，その生理的 な意義は十分には解明されていない。一方, GPCR のシグナル伝達の活性調節に, regulator of G protein signaling (RGS) が G タンパク質の GTPase 活 性化因子として働き，シグナルの不活性化を促進さ せる役割を担うことが示されている．RGS の種類 は 30 種以上の多種に渡り，その機能の解明が待た れている. GPCR の細胞膜における発現量はその 機能発現に深く係わるが，遺伝子発現を介した調節 機序についてはかならずしも十分には解明されてお らず，今後の解明すべき課題である。 また， GPCR が二量体化（あるいは多量体化）して存在すること が報告されている．この二量体化はホモ（同種）の 受容体で起こる場合とへテロ（異種）の受容体で起 こる場合が報告されているが，特にへテロの受容体 が二量体化した場合にはシグナル伝達の変化するこ とが考えられる，さらに，GPCR のシグナル伝達 が行われる場所は，細胞膜に均一に起こる訳ではな く，脂質ラフトと呼ばれるマイクロドメインにおい て行われることが最近明らかにされている。この脂 質ラフトにおける GPCR シグナルの調節機序の解 明も興味あるテーマである，GPCR 活性の様々な 調節機構を Fig. 1 に模式的に示した.

本誌上シンポジウムでは，GPCR の新たな機能 及び調節機構について最近の知見を述べるが，始め

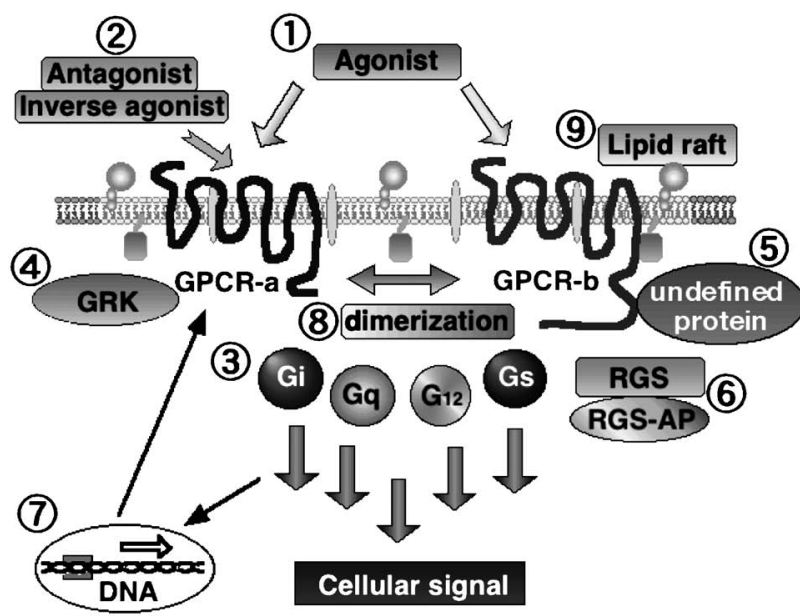

Fig. 1. Novel Functions and Regulatory Mechanisms of $G$ Protein-coupled Receptors (GPCR)

(1) Agonists with different chemical structure activate different $\mathrm{G}$ proteins through the same GPCR, (2) Inverse agonist reduces endogenous activity of GPCR, (3) there are four major groups of trimeric G proteins as first targets of GPCR-mediated signal, (4) G protein-coupled receptor kinase (GRK) phosphorylates agonist-occupied GPCR C terminus, (5) C-terminus of GPCR bound several undefined proteins, (6) regulators of G protein signaling (RGS) accelerate GTPase activity of G proteins, and RGS-anchoring proteins (RGS-AP) modulate the function of RGS, (7) GPCR gene/protein expression is regulated through GPCR signal positively or negatively, (8) hetero- or homo-dimerization of GPCRs change the signaling, and (9) lipid raft is a specific microdomain of cell membranes for GPCR signaling.

に GPCR のC 末に結合するタンパク質による機能 調節について，二番目に GPCR 発現の遺伝子を介 した調節について述べ，最後に GPCR の脂質ラフ トにおける活性調節について概説する。 